NS

Allele A

Allele B

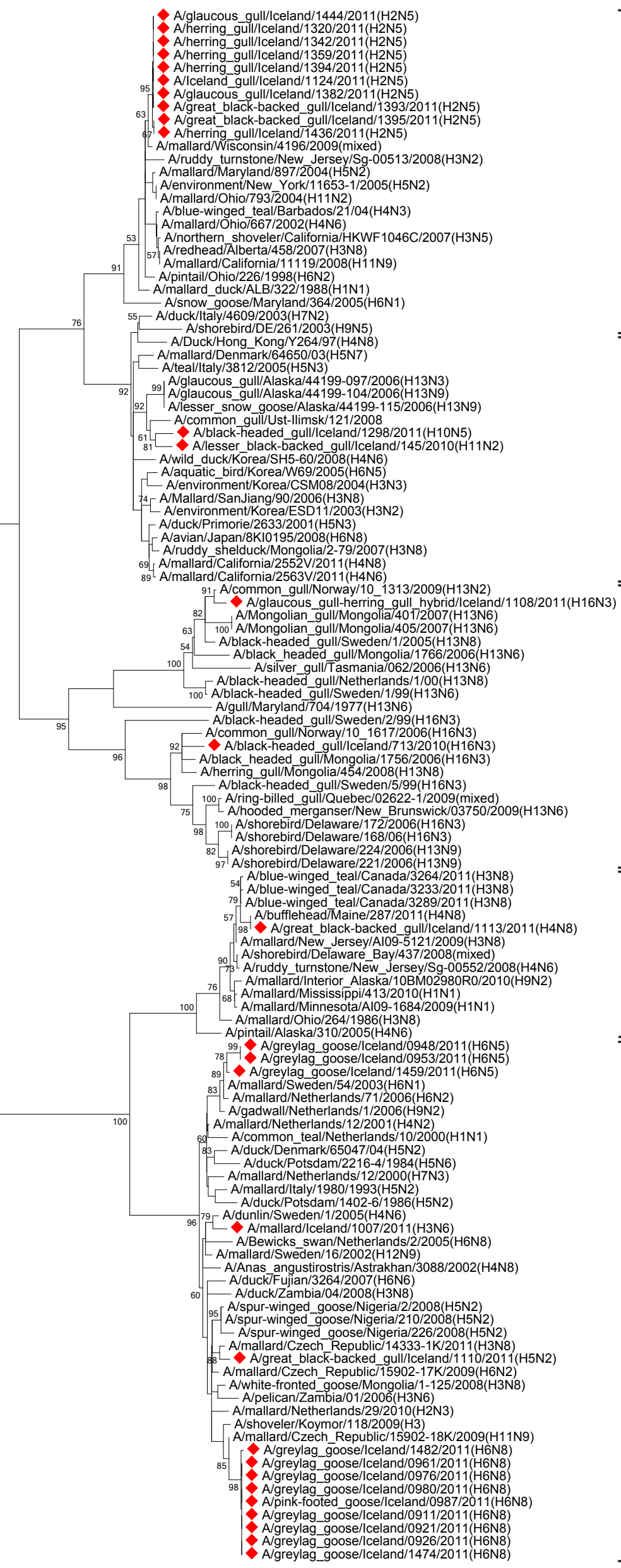

American

Lineage

Eurasian

Lineage

\title{
Gull/Shorebird Lineage
}

American

Lineage

Eurasian

Lineage 